\title{
The Psychological Transitions in the Character Portrayal of E.M. Forster's A Passage to India
}

Nilufa Akte

Lecturer

Department of English

City University

Bangladesh

nil.mishu@gmail.com

\begin{abstract}
A passage to India, of E.M. Forster, sheds light on the psychological journey of the main characters (Mrs. Moore, Mrs. Adela Quested, Dr. Aziz) who are connected to the incident of the Marabar caves. E. M. Foster has given the readers the opportunities to analyze and discuss the novel from various angles. Having the context in India and characters from the Britain, this text can be analyzed from different perspectives including colonial studies, political perspective, physical and mental passage of British people to India, cultural conflict, religious conflict, racism and so on. And all these issues along with Marabar Caves do create some impacts on the characters in different times as the storyline gets developed in the novel. The experience of the Marabar caves affected the minds of the characters and a great deal of transformation is observed among them. This paper highlights how the story of Dr. Aziz changes with the incoming of Adela and Mrs. Moore as well as how the deflection that occurs in the Marabar Caves incident transits these character's life into a new diverse vision. This paper also focuses how the journey
\end{abstract}


of the characters switches into a new mode of realization; find a new identity, new philosophy of life through the transitions.

Keywords: Cave, Journey, New mode, Passage, Psychological Transition, Transformation.

Introduction

E.M. Forster's A Passage to India is a novel which depicts various issues prevalent in British ruled India during the first half of $20^{\text {th }}$ Century. The Novelist presents Sociological and Psychological perspectives of Anglo-Indians (British Administrators or rulers) who want to preserve their rule and Indian people who want to be free from British rule. The plot construction of this novel actually revolves round several British and Indian people who start a journey to explore India especially, famous Marabar Caves of Chandrapore. This journey starts due to Miss Adela's fascination to know real India and through this journey, major characters of the novel experience psychological transitions, which act as a kind of catalyst to throw light on their inner selves. Major characters of this novel including Dr. Aziz, Mrs. Moore and Miss Adela Quested experience psychological transitions. The changes are in fact the self-transformations among the characters, which help them to move from a simple mode to a more complex mode of existence. No one who has entered the caves in a passage to India has escaped unscathed (Mahbub, 2015, p.179).

Tracy Pinchman starts his article on Snakes in the cave: Religion and the Echo in E. M. Forster's A Passage to India" with a quotation of June Perry Levine. In a survey of critical evaluations of the novel, June Perry Levin notes: 
"One important question--- is, whether A Passage to India is primarily a social and political novel, treating Anglo-Indian relations through the medium of satire, in which case the appositeness of Forster's presentation and the quality of his political commitment are matters of great consequence, or whether it is primarily a philosophical novel, transcending topicality to explore metaphysical significance or certain states of existence which India symbolizes."

The psychological transitions or the inner journey of the characters starts when they set foot towards the cave. Once they started their voyage to the cave, their lives stated getting changed gradually, which ultimately changed their attributes and features. Miss Adela's quest for real India leads to the caves and consequently results in the imprisonment and trial of Dr. Aziz; Mrs. Moore's new realization and decision to go home and who eventually dies on the way; Adela's engagement is broken, and the friendship between Aziz and Fielding is endangered.

\section{Literature Review}

Psychological transitions are common factors for humans if they exist, take breath and live in this world. They change frequently due to the experiences perceived from their surroundings; acquire new knowledge through better realization and moves to the new direction. This psychological transition of human being has become one of the most important subjects in literary writing for the writers from the time immemorial. Forster's A Passage to India is one of the representative documents which deals with the transitions of major characters from psychological perspectives. David W. Elliott in the article (needs intext citation with year/ according to the writing style) on "A Psychological Literary Critique from a Jungian perspective of E.M. Forster's A Passage to India" applies the psychological theories of C.G. Jung and the 
methodological postulates of Jungian literary critique, Terence Dawson, to examine the psychological implication of the text, especially in relation to the novel's characters. David mentions that critics like Stone, Dauner, Thompson and Claude Summers have especially understood the importance of psychological approach to the narrative, but none address the text in anyway like Dawson's would approach Passage. In this study, David explains that a major part of Dawson's methodology is to identify what he calls the "effective protagonist" of literary text. The effective protagonist is that character who is psychologically affected the most by the events of the narrative, that is, the character who undergoes the most change during the novel (Jung, 1954-67, p.257) sometimes, the text has an obvious character on a heroic journey, and the narrative tells about the changes the hero undergoes. David concludes the paper with the remark that, the Marabar Caves is the central psychological symbol of the narrative, representing what Jung calls the collective unconscious. According to his opinion both Adela Quested and Mrs. Moore, the effective protagonist of the novel, encounter heretofore unconscious material in the caves that precipitate psychological growth for each.

Rahman M. Mahbub (needs intext citation with year/ according to the writing style) in the article on "Beyond Sexual Anxiety: Experience and Mystery of the Marabar Caves in $A$ Passage to India" sheds light on the mystery of the Marabar Caves and mentions that Forster recognizes the mystery of human nature is beyond the power of humans, or even gods, to solve. According to Mahbub, the mystery lies deep within the very soul of man's inner being, and that is where its resolution must take place, if ever it does. He establishes that Mrs. Moore and Adela's experience are, in part, deeply psychological and also shows how the authors of $A$ Passage to India, Lord of the Flies and Heart of Darkness share similar themes. 
Keith Hollingsworth explores what the echoes suggest on the open or upper level and the allegory used in the text in the article on "A Passage to India: The Echoes in the Marabar Caves". He has prepared critical study on the instrumental function or use of echoes throughout the novel and explains that at the beginning of the second part, after the characters attend picnic and experience echoes turns them to be realistic.

Timothy Christensen finds out that most of the critics ignores and fails to explain moral and political chaos indicative of Indian reality. In the article titled, "Bearing the White Man's Burden: Misrecognition and Cultural Difference in E. M. Forster's A Passage to India", Timothy mentions that Forster's novel has potentials to be read as a radical criticism of British colonial practice, misrecognition and cultural differences between British and Indians.

Kieron Dolin analyzes A Passage to India as a document for hegemonic discourse of Anglo-India in the article on "Freedom, Uncertainty, and diversity: A passage to India as a critique of Imperialist Law" and Tracy Pinchman in his article on "Snakes in the cave: Religion and the Echo in E. M. Forster's A Passage to India" explores different interpretations of snake in the cave as well as the religious issues and the use of echo for the actions and reactions of the characters of A Passage to India.

E. M. Forster's A Passage to India attracts the attention of many scholars all over the world and they examine the novel from different perspectives. It is quite evident that this text can be analyzed from different perspectives including colonial studies, political perspective, physical and mental passage of British people to India, cultural conflict, religious conflict, racism and so on. But very few studies focus on the psychological transitions of major characters. So, in this paper, the focus is to show the psychological transition or journey of the major characters which make them self-aware at the end. 
Discussion

E. M. Forster's A Passage India deals with the psychological journey of several Anglo-Indian and Indian characters who have transformed due to the experiences or lessons following a picnic at Marabar Caves. They attend the picnic at the Marabar caves and after that they become more realistic towards life. "Thereafter we follow Mrs. Moore, Adela and Aziz on the famous picnic and through the distress which comes after it. The people continue to be realistic characters," (Hollingsworth, 1962, p.212).

Nicholous Poburko starts his article on "Transitional Passages: The Metaphysical art of E. M. Forster" with a quote from William James that is connected with the theme of this paper and worthy to be mentioned here for clear indication, "Life is in the transitions as much as in the terms connected; often indeed it seems to be there more emphatically..."

Mrs. Moore

In Foster's A Passage to India, Mrs. Moore deflects and engages to a place of prominence due to her transformation from the very beginning of the novel till the end, and she has gone through a journey or movement from the familiar into the unknown. In the novel, Forster presents the metaphysical connotation of Mrs. Moore's spiritual journey and portrays her movement from a simple to a more complex mode of existence where she is confused and observes the world with the feeling of 'Nothingness'.

At first, the author depicts her as an ordinary, elderly British tourist who is presented as a gentle, broad-minded, simple and spiritual woman, likes Indians, loves to go to the Mosque, carries the spiritual sensibility. She gets pleasure when she escapes from the club and be like a child after meeting Dr. Aziz. The author narrates her conversation with Dr. Aziz in the entrance 
of the mosque where she is simple, friendly and lover of scenic beauty. She is so simple that after the first meeting with Dr. Aziz, she starts to consider him as her friend and she says to Ronny and Adela that, "I like Aziz, Aziz is my real friend" (Forster, p. 111). But later she receives dramatic changes especially after the visit to Marabar Caves. At last, she has no interest for the scenic beauty, the trial of Dr. Aziz as well as for the Indian people. So, at the end, she has transformed dramatically and experienced brand-new realization that is totally different from earlier.

Mrs. Moore wants to be pleasant towards India and Indian People and Forster presents her feelings at the beginning. She does not have complex psychological pattern like her son, Ronny Heaslop, and she makes argument with her son regarding this perspective. She speaks strongly over the matter:

"Because India is part of the earth: and God has put us on the earth in order to be pleasant to each other. God... is...love.' She hesitated, seeing how much he disliked the argument, but something made her go on. 'God has put us on earth to love our neighbours and to show it, and he is omnipresent, even in India, to see how we are succeeding."

Later she develops different realization especially after her visit to Marabar Caves that provides new horizon to her thoughts and she totally ignores India and Indian people. Mrs. Moore with her new transformation perceives that she has nothing to do with Indians and she wants to go back to England although she dies in the Mediterranean Sea. "The Marabar Hills function as a variant of grotesque realism. Mrs Moore's experience is, in part, very human and deeply psychological." (Mahbub, 2015, p. 185).

At the first chapter, the novelist shows that Mrs. Moore is religious with strong faith on Christianity. She has the spiritual connection to God and nature. She is also vigorous, loves to 
enjoy. She is interested and excited to visit Marabar Caves after getting the invitation from Dr. Aziz and starts the journey with great pleasure but at the picnic spot, after visiting one cave she starts to feel uneasy and the gloomy environment of the cave provides panic and strife to her soul. It is suffocating for her and she is afraid of the sound 'Ou Boum'; it seems the sound is utterly dull for her. Mrs. Moore experience massive psychological transformation after visiting the first cave and she does not find any urge to visit another one. She has lost her faith on Christianity although earlier she had strong faith on Christianity. It may be so that she has equated the emptiness of the cave as the emptiness or nothingness of the universe. Things exist but these have no value to her. She finds that she even cannot write a letter to Ralph and Stella. A sense of nothingness perceived in her mind and it is clear from her activities and thoughts:

'She took out her writing-pad and began, 'Dear Stella, Dear Ralph,' then stopped, and looked at the queer valley and their feeble invasion of it. Even the elephant had become nobody. Her eyes rose from it to the entrance tunnel. No, she did not wish to repeat that experience." It can be said easily that nothingness has come in her life and she has turned into a new person. "Everything exists, nothing has value.' If one had spoken vileness in that place, or quoted lofty poetry, the comment would have been the same- 'Ou Boum'. (Forster, p.160).

"But suddenly, at the edge of her mind, Religion appeared, poor little talkative Christianity, and she knew that all its divine words from, 'let there be light' to 'it is finished' only amounted to 'boum'. Then she was terrified over an area larger than usual; the universe, never comprehensible to her intellect, offered no repose to her soul, the mood of the last two months took definite form at last, and she realized that she didn't want to write to her children, didn't want to communicate with anyone, not even with God." (Forster, p.160). 
Thus Mrs. Moore's perspectives for the universe have changed at the end of the novel and she has realized the emptiness of the universe. So, the complex psychological journey has started through her character and makes her indifferent towards the whole world. It may be so that she has perceived a call for her eternal journey to the after World.

She is very much involved herself with nature and usually likes to move onto her house in the evening after finishing her work in the club, she is so much engaged with nature. She has a great feeling about kinship, moon and stars. But following the visit to the caves, she becomes totally hostile and indifferent towards nature. She has lost gradually the interest of her life and become sick. She has lost interest on relatives and family and behaved indifferent regarding Aziz. Instead of all these she becomes interested in spirituality, good and evil, or truth and reality issue. She realizes that nature is indifferent and hostile. The novelist presents her mental state in the following comment:

"Her Christian tenderness had gone or had developed into a hardness, a just irritation against the human race; she had taken no interest at the arrest, asked scarcely any questions, and had refused to leave her bed on the awful last night of Mohurram, when an attack was expected on the bungalow." (Forster, P. 204).

Adela

Adela Quested and Mrs. Moore both envisage some credulous and unconscious ingredients in the caves that precipitate psychological growth for each (Elliott, 2005, p.2). No doubt, Mrs. Moore and Miss Adela's experience are, in part, are not materialistic, rather they are deeply psychological, which effect both in forming their characteristics (Mahbub, 2015, p.182). Adela's personal psychological journey throughout the novel changed her psychological pattern, and she is enlightened dramatically at the end. 
At the first chapter, the purpose of Adela's visit to India becomes quite evident and transparent. It is clearly understandable that Adela has come to India to marry Ronny Heaslop and to examine whether she can be habituated to the environment of India or not. She also wants to know real India and Indian people. She comes to Chandrapore with some dreams regarding her marriage and her future life with Ronny. But after passing time with Ronny and while living in Chandrapore, she gradually realizes the fact that her marriage with Ronny would be a delusion or wrong step for her future life. When she attends the tea party at Chandrapore, she announces in a group regarding her departure from India. These words are pronounced unconsciously but it turns to be a bitter truth at last. She is unaware about the upcoming future of her life and she makes this decision unconsciously, but it uncovers or blurts out spontaneously in her activities and it proves that some unconscious realization or changes are obvious. She comes to India to realize the bondage between her and Ronny, but she did not find any spouse or authentic relation between them. She becomes afraid regarding marriage and says, "I'm afraid I can't do that (Forster, p.90), which means that one wouldn't marry Ronny: "we must have a through talk, Ronny, I'm afraid." (Forster, p.99). These lines prove that Adela is in dilemma, puzzle and her transformation starts secretly. Adela tells Ronny that they are not to be married (Forster, p.89) and it is maintained like a business deal, business contract and it seems that they do some gambles together. They are talking like the way that they want to dismiss the marriage, but the surprising matter is that both of them remain calm, there is a mild disappointment, and they are deciding the matter mildly. No emotion or feelings are seen here, and it is the evidence that Adela is changing, and experiences changes slowly in her mind. 
At first, Adela is really confused regarding her relationship with Ronny. She knew Ronny in England but after coming to India sometimes Adela feels that Ronny is different. In chapter VII, Adela's thought is revealed:

"India had developed sides of his character that she had never admired. His self-complacency, his consciousness, his lack of subtlety, all grew vivid beneath a tropic sky; he seemed more indifferent than of old to what was passing in the mind of his fellows, more certain that he was right about them or that if he was wrong it didn't matter. At one point she told Ronny that 'I've finally decided we are not going to be married, my dear boy.” (Forster, p.99).

The transition of Adela is apparent here although it is not the final transition regarding the marriage or relationship. But at the end, she finds out that the decision of marriage is wrong, and she starts to avoid the thinking of the dream of her marriage with Ronny. She is determined about her decision and acted like a smart woman who can see the real picture of her life and accepts the reality.

Adela Quested has gone through massive transitions after visiting Marabar Caves. In the cave Adela thinks of her relationship with Ronny and finds out that she and Ronny do not love each other. She is going to marry without any love, without any feeling and this feeling provokes her thought. This realization or feeling is like electric shock and at this point she starts to think that Aziz is sexually attracted to her and it is prevalent in her imagination. She repeatedly sounds 'Ou Boum' in the first cave which represents her inner in the subconscious mind. This realization changes her whole life and she becomes determined about her activities. Now Adela's sensibilities are not latent, her emotions, feelings are active, and she can realize that Ronny has some expectations regarding to her and their marriage. She realizes this fact and it is very tough for her to maintain all the decisions of Ronny and she does not salute bow to his every opinion. 
She is ireful and wrathful towards Ronny for this grim realization and admits to herself that Ronny, and she do not love each other and in this situation she becomes ruined. Aziz becomes handsome and attractive to Adela when she realizes this fact. Adela moves intellectually by Aziz's attractiveness, but her feelings remain hidden, and concealed. She does not express her emotions. She describes his beauty like "thick hair and a fine skin" (Forster, p.163). She was thinking about these before entering into the second cave. Her mind is occupied with the thought of Aziz not of Ronny or she thinks of physical connection towards Aziz not towards Ronny. Hence her mind shifts here with massive psychological transformation.

Adela wants to believe in the universal brotherhood and express this to Aziz. She realizes after the cave incident that it's not possible to believe in universal brotherhood and realizes that she wants to know India but not to love India; she wants to understand Indians without loving them which is not working at all. Cave exposes her barren emotional life. Adela becomes realistic regarding her life after the accident of Marabar caves.

Adela has changed drastically after the trial of Dr. Aziz. She accepts that her desire to know real India is not possible anymore. After the attack, she refuses to become the "darling" and she becomes indignant (Forster, p.202). Adela dissatisfies Ronny as well as the AngloEnglish society because she is confused about the issue of rape, the condition of the cave. Ronny and Anglo-English society want to give punishment to Dr. Aziz, but Adela does not say anything against Aziz. She refuses to give the proper statement of the story in the court and that means she is no more like the woman at first. She has changed herself and tries to ignore so called darling wife.

"Adela's transformation after the trial is not simply one of disillusionment, but one of personal regeneration" (Christensen, 2006, p.175). 
"It is an irony both comic and pitiful: the young woman who cares for truth is thus caused to tell a falsehood; the person who most wanted to meet and know India becomes the agent of a greater division than any caused by Turtons and Burtons." (Hollingsworth, 1962, p.213).

Now she has become strong and can take decision based on reality. She has taken the decision that she needs to go back to England. Initially she was a girl with innocence; she was a simple girl with a lot of confusion which made her do a lot of mistakes in every step of her life. Now she becomes more confident rather than the past. She becomes bold and can take her own decision. Forster writes the following sentence which shows the transformation of Adela:

"Although her schoolmistressy manner remained, she was no longer examining life, but being examined by it; she had become a real person.” (Forster, p. 245).

\section{Doctor Aziz}

Dr. Aziz experience psychological transitions like Mrs. Moor and Adela and enlightens his inner self that makes him strong to survive and to shed new light on his self-understanding and realization.

At the beginning of the novel, Forster presents Dr. Aziz as simple and easy-going person who is devoted to Islam, likes to spend time with friends and to visit Mosques. It seems he loves to lead easy and simple life; does not like to make comparison with others. Later following his visit to the caves and the trial at the court, Aziz has changed drastically. He is not a simple and easy going individual anymore rather he has developed distinct psychological pattern inside his heart as well as he grew as more complex and suspicious one. It is also evident from the study of the novel that at the beginning Aziz is friendly and cordial. He makes friendship with Mrs. Moore within few minutes and starts to consider her as friend as well as at the very first 
meeting with Henry Fielding, Aziz makes friendship and calls him (Fielding) as brother. He becomes happy and excited when he discovers Mr. Fielding as cordial and friendly too and within a spur of the moment shows the photograph of his wife to fielding describing what is preserved in his mind. Aziz makes a comment at one point stating that:

"All men are my brothers, and as soon as one behaves as such he may see my wife." (Forster, p.128).

Aziz has transformed dramatically following his visit to the caves and the trial at the court. He is not a Cordial and friendly individual anymore rather he has developed distinct psychological pattern inside his heart as well as he grew as more unfriendly and harsh. Now Dr. Aziz is strict and strong who does not like to make friendship easily and believe anyone without hesitation rather becomes bold to express his thoughts directly. Now Aziz is fully aware of the harsh reality and becomes materialistic and suspicious in nature. Aziz suspects that Fielding will go to England and marry Miss. Quested for money. He actually develops this misconception after reading two or three sentences from a letter of Fielding and later he destroyed the subsequent letters unopened. At Mau, Aziz continues to believe the misconception and Fielding has turned to be a foe to him. Aziz thinks Fielding as selfish without knowing anything real. Fielding has come to Mau with his wife, Stella and brother-in-law, Ralph but Aziz does not want to meet with Fielding. Aziz is angry and indifferent after receiving the news from professor Godbole and the author carefully explains his thought:

“Aziz knew who 'he' was-Fielding-but he refused to think about him, because it disturbed his life, and he still trusted the floods to prevent him from arriving." (Forster, P. 288).

So, he is totally different and most of his previous views regarding life have changed. This suspicion cannot be removed easily as he has developed grim realization and it's not only 
towards Fielding but also towards the whole Anglo-Indian community. The author successfully depicts his inner state in the following remark:

"Suspicion and belief can in his mind exist side by side. They sprang from different sources and need never intermingle. Suspicion in the oriental is a sort of malignant tumor, a mental malady, that makes him self-conscious and unfriendly suddenly;" (Forster, p. 275-276).

When Fielding removes the misconception and tells that he has married Stella, the daughter of Mrs. Moore, Aziz is in rage and says:

"What does it matter to me who you marry? Don't trouble me here at Mau is all I ask. I do not want you, I do not want one of you in my private life with my dying breath I say it." (Forster, p. 298). He further continues, "My heart is for my own people henceforward" and turned away." He expresses his standpoint towards having the Englishmen and women as his pal. He strongly argues that, "I wish no Englishman or Englishwoman to be my friend." (Forster, p. 298).

Dr. Aziz also experiences certain changes regarding his personal realization over various issues of life after getting the bitter experience from his trial at the court. The author mentions at the first chapter that Aziz is very conscious regarding his reputation in society and always suppress the desire to love someone after the death of his wife. He has three children at the village and he always thinks that his misdeeds will bring disgrace for his children, to his family. He dreams of having love of woman but cannot go further and comes back to reality. He wants love but cannot have it because of the society and for the fear of disgrace on his children. Later when he is arrested for molesting Adela in the cave, he is very much concerned not for himself but for the disgrace he has brought for his children. The writer has explained his state of mind through the following remark: 
"After he was arrested for the blunder he thought of his children and said, 'My children and my name!' he gasped, his wings broken.'” (Forster, p. 172).

The blunder at Marabar Caves and the disgraceful trial serve as a lesson for Aziz and he realizes that it is better to be married and get love from family. So, at Mau, Aziz is married again, and his children are with him. It happens because the disgrace he fears, at last, shatters his gentleman like image and he already experiences bitterness at the court for a false conviction without doing any harm to anybody. Henceforth this incident makes him self-conscious and he learns not to suppress his desire anymore. This is a drastic psychological transformation for Aziz; who did not want to marry for the disgrace before the trial is now married second time. Another change in the character portrayal of Dr. Aziz is worthy to mention and which is apparent from the text is related to his attitude towards Hindu Community of India. At first Aziz had the dissatisfaction and frustration for Hindus and in first chapter his dissatisfaction has been depicted clearly:

"Slack Hindus- they have no idea of society; I know them very well because of a doctor at the hospital. Such a slack unpunctual fellow! It is as well you did not go to their house, for it would give you a wrong idea of India. Nothing sanitary. I think for my own part they grew ashamed of their house and that is why they did not send." (Forster, p.46).

But after the trial especially at Mau, Hindus are dearer to him and he even becomes the family physician of Hindu Rajah at Mau. His realization is that the Indians have nothing to do with British or Anglo-Indians and also realizes that both Muslims and Hindus have to be together to fight against British rule.

Another significant or crucial transition is related to his opinion regarding British rule as at the very beginning Aziz seems to be indifferent or it can be worthy to mention that he has no 
headache regarding English people and their rule or in a word it is the fact that he is not much concerned with British rule. He tries to spend most of his time with religion instead of thinking much about British India. This claim is evident from the following remark of Aziz which he expresses at the first chapter with his friends:

"Why talk about the English? Brrr ...! Why be either friends with the fellows or not friends? Let us shut them out and be jolly." (Forster, p.35).

Later the narrator shows the dramatic changes of Dr. Aziz following the picnic at Marabar Caves and the trial at the court for molesting Adela. Aziz who is impartial or had no headache for British rule now has the view against the British rule and he is afraid because of his trial at Chandrapore. His learned lesson from the expedition of the caves and the consequent trial changes his point of view regarding British rule and it is captured in the following remark of the novelist:

"His impulse to escape from the English was sound. They had frightened him permanently, and there are only two reactions against fright: to kick and scream on committees, or to retreat to a remote jungle, where the sahib seldom comes.” (Forster, p. 289).

Aziz has become so strong after the disgraceful trial that no one can change his perspectives. At the end, Fielding has removed the clouds of misconception and spent time together with Aziz. But both of them realized that they cannot be united, they are different. Now no one can easily break the strength of Aziz and his views regarding the freedom of India. At the reply to the Fielding he says;

"If I don't make you go, Ahmed will, Karim will, if it's fifty or five hundred years we shall get rid of you, yes, we shall drive every blasted Englishman into the sea,". Aziz at last realized that "two nations cannot be friends." (Forster, p.316) 
So, throughout the novel, Dr. Aziz has transformed a lot and he has become a new person who is strong, sharp and self-conscious and Forster successfully reflects how Dr. Aziz shifts from simple to a more complex mode of existence and transformed thereby.

\section{Conclusion}

E. M. Foster's A Passage to India is actually a depiction of the transformations of some of the characters such as; Mrs. Moore, Mrs. Adela and Dr. Aziz; whose lives have been altered after the mysterious incident in the Marabar Caves. The cave itself played the most pivotal role in this transformation which the authors here have tended to establish. After the mysterious experience of the cave, the life of the characters has changed, and they lose their individual identity and start a new journey of their lives. These changes have come in their psychology, in their vision of mind, in their belief on religion. Both Mrs. Moore and Adela have a strong desire to see the real India but at the end of the novel they discover the new vision of life. Mrs. Moore has lost her faith on Christianity and changed her perspective about the universe. She observes the world with the feelings of "nothingness", emptiness of the universe and realizes the nature as a hostile. In the case of Adela, she realizes the reality and takes a decision to break up the marriage with Ronny Heaslop. She becomes more confident, courageous, and bold rather than she was in the past. Dr.Aziz becomes a complex, complicated person who was a simple at the beginning of the novel. After the trial scene, he has transformed into a new man and gets a new identity. 


\section{Works Cited}

Christensen, T. “Bearing White Man’s Burden: Misrecognition and Cultural Differencce in E. M. Forster's A Passage to India" Novel: A Forum on Fiction, vol.39, No.2, 2006, pp. 155178, Duke University Press, doi: 10.1215/ddnov.039020155. web.24 July.2018.

Dawson, Terence. The effective protagonist in the nineteenth-century British novel: Scott, Bronte, Eliot, Wilde. Routledge, 2016.

Dolin, Kieran. "Freedom, uncertainty, and diversity: A Passage to India as a critique of imperialist law." Texas studies in literature and language 36.3 (1994): 328-352.

Elliott, David. W. “A Psychological Literary Critique from a Jungian Perspective of E. M. Forster's A Passage to India.” (2005). Electronic. Theses and Dissertations, Paper 1069. http://dc.etsu.edu/etd/1069.

Forster, E. M. A Passage to India. $3^{\text {rd }}$ ed., Ed. Oliver Stallybrass, Penguin Books Ltd,1979, PP.31- 316, 27 Wrights Lane, London W85TZ, England. [ All textual references are to this edition.]

Hollingsworth, Keith. "" A Passage to India": The Echoes in the Marabar Caves." Criticism 4.3 (1962): 210-224.

James, William., “A world of Pure Experience”.Essays in Radical Empiricism,1996. Longmans, Green and Co., 1912.

Jung, C.G. Collected Works. Trans. R.F.C. Hull.Ed.Sir Herbert Read, Michael Fordham And Gerhard Adler. Princeton UP, Bollingen Series,20,1954-67.

Levin, June perry. "An Analysis of the Manuscripts of A Passage to India". PMLA 85 (1970): 284-94. JSTOR, 4 May. 2005, http://www.jstor.org/search 
Mahbub, Rahman. M. "Beyond Sexual Anxiety: Experience and Mystery of the Marabar Caves in A Passage to India" Ideas, vol.1, September 2015, pp.179-194

Pintchman, Tracy. "SNAKES IN THE CAVE: Religion and the Echo in EM Forster's" A Passage to India"." Soundings (1992): 61-78.

Poburko, Nicholas. "Transitional passages: The metaphysical art of EM Forster." Renascence 54.1 (2001): 23-45. 